\title{
Building a synergy between mentors' field practices and teacher-trainees' performance in student teaching
}

\author{
Gail G. Gumilet, Bonimar T. Afalla, Sanny J. Dangis
}

College of Teacher Education, Nueva Vizcaya State University, Philippines

\begin{tabular}{l} 
Article Info \\
\hline Article history: \\
Received Jan 14, 2021 \\
Revised Jun 19, 2021 \\
Accepted Jul 16, 2021 \\
\hline
\end{tabular}

\section{Keywords:}

College dean

Cooperating teacher

School principal

Supervising instructor

Teaching performance

\begin{abstract}
The gradual change from the position of a teacher-trainee to the role of a teacher depends on effective teamwork between educational institutions and the wider education community. Hence, this study ascertained the relationship between the field practices of college deans, supervising instructors, school principals, and teachers and the teaching performance of teacher-trainees. A descriptive-correlational study was employed in this study. A rating scale was used to collect data from the mentors and teachertrainees who served as respondents. Descriptive statistics such as frequency counts, percentages, and weighted means were employed to describe the levels of mentors' field practices and teaching performance of teachertrainees. To establish a significant relationship between the variables, the Spearman rank-order of correlation coefficient was used. Results of the study show that when the deans, supervising instructors, school principals and cooperating teachers manifest an exceptional level of field practices in student teaching, it follows that all the dimensions of field practices are highly practiced. Further, when the teacher-trainees exhibit an exemplary teaching performance, all other dimensions of student teaching are also found to be remarkable. Finally, an outstanding field practice in the student teaching shows minor or slight influence in the outstanding teaching performance of teacher-trainees.
\end{abstract}

This is an open access article under the $\underline{C C B Y-S A}$ license.

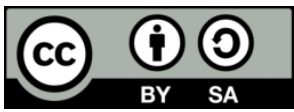

\section{Corresponding Author:}

Bonimar T. Afalla

College of Teacher Education

Nueva Vizcaya State University

Bayombong, Nueva Vizcaya, 3700 Philippines

Email: bonimarafallatominez0508@gmail.com; bonnafalla@nvsu.edu.ph

\section{INTRODUCTION}

The advancement of comprehensive reform in professional training is one of the priorities of Education for All (EFA) [1] which has led to a mandate for well-trained and certified teachers [2], [3]. Thus, the Higher Education Commission (CHED) has advised all Higher Education Institutions (HEIs) to upgrade the value of Filipino education by providing exemplary experiences to potential teachers. Besides, CHED has authorized all Teacher Education Institutions (TEIs) to strengthen their education systems by establishing great aspirations in defining the goals, practices, and systems of their programs and providing preservice teachers with clear, objective-oriented, and contextualized experiences [4], [5].

The core feature of the New Teacher Education Curriculum (NTEC) is Experiential Learning Courses (ELCs). ELCs are off-the-shelf opportunities that highlight the value of realizing the intricacy of teaching, especially in this period of globalism. ELCs provide teacher-trainees with access to the school environment to carry out their acquired ideas to practical practice [6]. The National Competency-Based Teacher Standards (NCBTS) of the Department of Education (DepEd) is a quality standard that covers 
realms that are performed throughout the ELCs. These areas comprise social respect for learning; the school environment; the student characteristics; the curriculum; preparation, assessment, and reporting; support networks; and self-improvement and career development [7]. The establishment of criteria for effective teaching is a positive step towards the promotion of the teaching profession [8], [9].

Student teaching is the pinnacle of all teacher training courses. It is the complete integration of the teacher-trainee into the actual life of being a teacher [10]. At the phase of exposure, a trainee encounters the fundamentals of teaching in a gradual preparatory phase, actual teaching, and evaluation of learning. A teacher-trainee goes through the entire teaching-learning process with a coach named the cooperating teacher. In this sense, the teacher-trainee brings into effect the material and theoretical lessons, techniques, or ways of instruction and even the general pedagogical experience gained in rigorous coursework before the practice teaching [3], [11].

Student teaching induces a variation of excitement, fear, and uncertainty in the teacher-trainees as they begin to immerse themselves [12]. It was clarified that teacher training is an educational task that requires a teacher-trainee to bring his learned theory into effect based on the true experience of a typical classroom setting [13]. Also, Ogonor and Badmus [14] argued that this is an occasion for prospective teachers to confront the complexities of their chosen career path in terms of their pressures, difficulties, and motivation. There can also be times where they are encouraged to bring into action the ideas and values of education that they have learned at school while they teach. It represents an opportunity for all of them to be introduced to the reality of teaching and the challenges they may face in the education field [15]. It is at this point that they will be encouraged to recognize themselves deeper, to appreciate the essence of their career, and to learn basic instructional skills needed to make a critical examination of the multiple issues relevant to teaching. The training they can have throughout their assignment will help them improve their teaching skills [16]. Salcedo [17] also emphasized that effective teaching is thrilling yet demanding. Besides, it was reported that perhaps the teaching career represents the fourth spot on the list of demanding jobs. Consequently, this profession, particularly in the early years, requires more effort on behalf of the teacher to prevent any terrifying situation and to educate people about the school climate [18].

Classrooms guided by actual views on teaching methodologies will require a shift in the approach to teaching away from an increased-structure approach into a more reduced-structure orientation [19]. While Haigh, Pinder, and McDonald [20] noted that even if teacher trainees were involved in classroom instruction but with the continuous guidance of their cooperating teachers, they would master the importance of training. Meneses, et al. [21] found that the experience of prospective teachers in practicum wasn't quite as successful as they found it very hard to implement the principle, they had established in their training program in real classroom instruction.

In reality, work immersion helps teacher-trainees to know how the world works and let them realize the challenges and difficulties of teaching that they will face in the future. Even so, the pressures and standards of teacher training can be too daunting for others, providing a sense of frustration and a state of disparagement among them [22]. Given the important innovation of student teaching, teacher-trainees often experience difficulties that can, in some way, impede their capacity to efficiently portray themselves as teachers [23]. Recognizing their perspectives can make it easier for the teaching faculty, schools, and universities to become aware of the difficulties the teacher-trainees face during their academic life, which could result in a negative mindset towards the discipline. Thus, teacher-trainees are influenced by many individual and collective problems that interrupt their teaching efficiency [24].

Believing that effective preservice teacher training is the gateway to quality education in the country, CHED collaborated with the Department of Education (DepEd) through a Joint Memorandum Order where they set out certain guidelines on the deployment of teacher-trainees. The guidelines included roles of teacher education institutions and school division superintendents in the teaching practice of teacher-trainees; the identification of cooperating schools, cooperating teachers and their powers and responsibilities; and the obligations of teacher trainees [25]. As a training ground for teachers, the Nueva Vizcaya State University (NVSU) through its College of Teacher Education (CTE) needs to review its own operational approaches in terms of the Student Internship Program to optimize its program, the fact that the college is now on its way to competing in the global market, as shown in the high-performance level of the qualifying examination in past years.

It is with this context that this research explored the experiences of the trainee-teachers on their internship journey and how their mentors supervise them. The findings of this study are expected to further improve the professional practice of developing a workable and effective student internship program model to be used by college administrators, department heads, cooperating principals and teachers, and all teacher trainees. This study determined the field practices of mentors in student teaching and the teaching performance of teacher trainees. Specifically, this study sought to: 1) Determine the level of teaching performance of teacher-trainees; 2) Determine the level of field practices of mentors in student teaching as 
observed by themselves and their teacher-trainees; and 3) Determine if there are significant relationships between and among the dimensions of field practices of mentors in student teaching and the dimensions of teaching performance of teacher-trainees.

\section{RESEARCH METHOD}

A correlation study was employed in this research. Document scanning was done to further substantiate the theme of this study. This was conducted at the College of Teacher Education of NVSU and the selected secondary and elementary schools of the DepEd, Schools Division of Nueva Vizcaya, Philippines.

The first set of respondents included the college deans (CD) and supervising instructors (SI); the second set of respondents included the school principals (SP) and cooperating teachers (CT); and, the third set of the respondents are the teacher-trainees who evaluated the field practices in student teaching of their CD, SI, SP, and CT. Total enumeration was employed for CD and SI while a stratified proportional random sampling method was utilized to determine the sample for SP, CT, and teacher-trainees. Slovin formula with $5 \%$ margin of error was used to determine the sample size. Moreover, the fishbowl technique was employed to specifically identify the respondents of the study.

A structured questionnaire was used in this study. This questionnaire gathered pertinent data that substantiated the theme of this study. Dimensions and indicators of field practices were derived from DepEd Order No. 3, s. 2007. To ensure and strengthen its internal validity, this instrument was validated by experts in the field and has a Cronbach Alpha of 0.86. Further, a standardized rating scale for student teaching was employed to derive the teaching performance of teacher-trainees as evaluated by their cooperating teachers and supervising instructors along with six dimensions such as teacher's personality, lesson planning, content, teaching method, classroom management, and questioning skills. The teacher-trainees were evaluated in their first and final demonstration teachings.

To conform to the ethical standards and practice of research, the researchers sought permission from the University President and the Schools Division Superintendent for the conduct of this study. The administration and retrieval of the questionnaire were personally done by the researchers. Gathered data were tallied and subjected to a statistician for statistical analysis and interpretation.

Weighted mean was employed to describe the level of field practices and the level of teaching performance of teacher-trainees. To test the distribution of scores of teaching performance and field practices in the student teaching program, the test of normality was employed. To establish a significant relationship between the variables, the Spearman rank-order of correlation coefficient (rs) was used.

\section{RESULTS AND DISCUSSION}

\subsection{Level of teaching performance of teacher-trainees}

Table 1 presents the level of teaching performance of teacher in terms of age, sex, course, and type of evaluators. Results indicate that, regardless of age, the teacher-trainees exhibited a very satisfactory performance in their student internship. Similarly, the teacher-trainees, whether male or female, manifested a very satisfactory performance in their student internship displaying outstanding performance in dimensions such as teacher's personality lesson planning, and classroom management. Further, they exhibited a very satisfactory performance in teaching method, content, and questioning skills. The teacher-trainees under the Bachelor of Elementary Education (BEEd) program appeared to manifest higher ratings in all of the dimensions of student teaching displaying an outstanding teaching performance than those teacher-trainees from the Bachelor of Secondary Education (BSEd) program whose teaching performance is very satisfactory. It could be noted from the table that the CT evaluated their teacher-trainees higher than the SI. Overall, the teacher's personality and lesson planning were the dimensions with high ratings while content and questioning skills remained to be the dimensions with low ratings. Results reveal that the teacher-trainees of the University excel more in the teacher's personality and lesson planning.

The teacher-trainees manifested the admirable personality of the teacher, which indicates that they have brought into the teaching-learning atmosphere a well-rounded personality that motivates their learners to remain centered on the subject. This further suggests that in the teaching climate, they demonstrate a unique disposition as they were equipped to be living models for their students. And this could be predicated on the notion shared by teachers and college students that "self" seems to be the amazing image that he or she may provide to his or her students.

Also, the teacher-trainees showed an outstanding performance in the planning of lessons, which shows that they organize their teaching well by choosing learning experiences that are relevant to the subject. They also design state-of-the-art learning activities that are important to the goals of the session. This also 
demonstrates that their pedagogical teachers have trained them to organize their lesson plans quickly and effectively. This may also be due to the proper supervision provided by their cooperating teachers and their receptiveness to critical suggestions from those who tutored them in the art of teaching.

Besides, the teacher-trainees have been rated as very satisfactory in classroom management, suggesting that they are very good at preparing and enforcing procedures that help to get things started quickly and surely, as well as creating rules that mitigate disturbance and ensure safety. Additionally, the teacher-trainees have shown a very satisfactory output in teaching methods, reflecting the persistent adaptation of teaching strategies that relate the goals of the teaching with the needs, skills, and interests of the pupils. Besides, teacher-trainees use a range of instructional technology to stimulate the minds and creativity of the learners.

Moreover, the teacher-trainees manifested a very satisfactory performance in content which may be attributed to how they were taught by their pedagogy teachers to be consistent in bringing learning experiences that have a direct bearing with the lesson. Additionally, they were constantly reminded to connect the subject matter with the learner's experiences to make learning more meaningful and interesting.

Finally, in their questioning abilities, the teacher-trainees were tested very satisfactorily, which means that they are better at developing their learners' higher-order thinking skills. They also illustrate the method of asking questions that contribute to the creation and comprehension of the lesson. Generally, the very satisfactory teaching performance of teacher-trainees could be attributed to the College's strict adherence to admission and retention policies of the University and as mandated by the CHED Memorandum Order (CMO) \#30, s. 2004 and CMO \#52, s. 2007.

In their paper, Vecaldo, et al. [26] claimed that educational institutions in the Philippines are required to continue providing quality, appropriate, and objective experiences to preservice teachers. Somblingo [27] reiterated that teacher-trainees must be subjected to an improved and goal-oriented program to promote and deepen their interpretation of the instructional content and their pedagogical skills for them to reasonably share their experiences with their learners.

Table 1. Level of teaching performance of teacher-trainees when grouped according to grouping variables

\begin{tabular}{|c|c|c|c|c|c|c|c|c|c|}
\hline \multicolumn{2}{|c|}{ Grouping characteristics } & \multicolumn{7}{|c|}{$\begin{array}{c}\text { Mean rating } \\
\text { Dimensions of teaching performance }\end{array}$} & \multirow{3}{*}{$\begin{array}{c}\text { QD } \\
\mathrm{O}\end{array}$} \\
\hline & & \multirow{2}{*}{$\begin{array}{c}\mathrm{TP} \\
1.17\end{array}$} & \multirow{2}{*}{$\begin{array}{c}\text { LP } \\
1.16\end{array}$} & & & & & \multirow{2}{*}{$\frac{\text { Overall }}{1.23}$} & \\
\hline Age & $18-20$ years & & & 1.27 & 1.24 & 1.19 & 1.35 & & \\
\hline & $21-23$ years & 1.28 & 1.28 & 1.37 & 1.32 & 1.30 & 1.45 & 1.33 & VS \\
\hline & 24-26 years & 1.19 & 1.23 & 1.34 & 1.31 & 1.23 & 1.37 & 1.28 & VS \\
\hline & 27-29 years & 1.15 & 1.30 & 1.30 & 1.25 & 1.23 & 1.28 & 1.25 & VS \\
\hline & 30 and above & 1.21 & 1.21 & 1.31 & 1.27 & 1.23 & 1.39 & 1.27 & VS \\
\hline & Overall mean & 1.20 & 1.24 & 1.32 & 1.28 & 1.24 & 1.37 & 1.27 & VS \\
\hline & QD & $\mathrm{O}$ & $\mathrm{O}$ & VS & VS & $\mathrm{O}$ & VS & VS & \\
\hline \multirow[t]{4}{*}{ Sex } & Male & 1.21 & 1.20 & 1.31 & 1.27 & 1.23 & 1.39 & 1.27 & VS \\
\hline & Female & 1.21 & 1.24 & 1.35 & 1.28 & 1.24 & 1.41 & 1.29 & VS \\
\hline & Overall mean & 1.21 & 1.21 & 1.31 & 1.27 & 1.23 & 1.39 & 1.27 & VS \\
\hline & QD & $\mathrm{O}$ & $\mathrm{O}$ & VS & VS & $\mathrm{O}$ & VS & VS & \\
\hline \multirow[t]{4}{*}{ Course } & BEEd & 1.11 & 1.07 & 1.17 & 1.15 & 1.16 & 1.25 & 1.15 & $\mathrm{O}$ \\
\hline & BSEd & 1.28 & 1.30 & 1.41 & 1.36 & 1.28 & 1.48 & 1.35 & VS \\
\hline & Overall mean & 1.21 & 1.21 & 1.31 & 1.27 & 1.23 & 1.39 & 1.27 & VS \\
\hline & QD & $\mathrm{O}$ & $\mathrm{O}$ & VS & VS & $\mathrm{O}$ & VS & VS & \\
\hline \multirow{6}{*}{$\begin{array}{l}\text { Type of } \\
\text { evaluators }\end{array}$} & Cooperating teachers & 1.27 & 1.28 & 1.38 & 1.31 & 1.30 & 1.44 & 1.33 & VS \\
\hline & Supervising instructors & 1.28 & 1.31 & 1.43 & 1.39 & 1.26 & 1.52 & 1.37 & VS \\
\hline & Overall mean & 1.28 & 1.30 & 1.41 & 1.35 & 1.28 & 1.48 & 1.35 & VS \\
\hline & QD & VS & VS & VS & VS & VS & VS & VS & \\
\hline & Grand mean & 1.23 & 1.24 & 1.34 & 1.29 & 1.25 & 1.41 & 1.29 & VS \\
\hline & QD & $\mathrm{O}$ & $\mathrm{O}$ & VS & VS & VS & VS & VS & \\
\hline
\end{tabular}

Note: TP (teacher's personality), LP (lesson planning), C (content), TM (teaching method), CM (classroom management), and QS (questioning skills)

\subsection{Level of field practices of mentors in student teaching}

\subsubsection{College deans, supervising instructors, school principals, and cooperating teachers}

Table 2 shows the level of field practices in student teaching of CD, SI, SP, and CT as perceived by themselves. Results indicate that in student teaching, the CD excellently adhere to their roles and obligations and oversight. In adherence to policies and standards, however, they rated themselves very satisfactory. This is because they embrace the fact that they have not adopted or enforced some of the policies listed in the report. In general, they displayed outstanding student teaching practices. Results indicate that the deans significantly ensure that all is set before student teachers are deployed in their partnering schools, such as receiving approval and endorsements from the Superintendent of the Schools Division after the Building a synergy between mentors' field practices and teacher-trainees' performance ... (Gail G. Gumilet) 
Memorandum of Agreement has been signed by all parties; requiring student teachers to be well prepared with their skills and that guidance should be provided.

The SI of the BEEd program evaluated themselves as outstanding in all of the dimensions. The SI of the BSEd program evaluated themselves to be outstanding in three dimensions: adherence to assessment, duties, and responsibilities, and adherence to supervision. Surprisingly, they evaluated themselves to be very satisfactory in their field practices along with adherence to policies and standards but still indicates an outstanding level of field practices. Overall, SI of both levels observed themselves to be outstanding in their field practices. The SI highly observed themselves to be excellent in their adherence to assessment, duties, and responsibilities, and adherence to supervision but appeared to be very satisfactory in their adherence to policies and standards. Results indicate that the supervising instructors of the university exhibit excellent practices in evaluating the student teachers in terms of how they carry themselves and in managing their classrooms; in conducting regular visits to the cooperating schools to facilitate better collaboration; and, in giving feedback to the student teachers to motivate them to become effective in their teachings.

The SP for the BEEd program rated themselves to be outstanding in adherence to supervision, and duties and responsibilities. In the BSEd program, the SP observed themselves to be outstanding in their duties and responsibilities and adherence to supervision. In general, SP of both programs evaluated themselves to be outstanding in their field practices particularly in supervising the teacher-trainees and in doing their duties and responsibilities as cooperating school heads.

The CT of both programs observed themselves to be outstanding in their field practices along with the dimensions' adherence to assessment, adherence to supervision, and duties and responsibilities. This implies that they excellently do their tasks as mentors by adhering as closely as possible in evaluating, providing feedback, and monitoring the progress of the student teachers.

Table 2. Level of field practices of mentors in student teaching as observed by themselves

\begin{tabular}{|c|c|c|c|c|c|}
\hline \multirow{2}{*}{\multicolumn{2}{|c|}{ Dimensions of field practices }} & \multicolumn{3}{|c|}{ Mean rating } & \multirow{3}{*}{$\begin{array}{c}\text { Qualitative } \\
\text { description }\end{array}$} \\
\hline & & Elementary & Secondary & Overall & \\
\hline \multirow[t]{4}{*}{ College deans } & Duties and responsibilities & - & - & 4.70 & \\
\hline & Adherence to policies and standards & - & - & 3.60 & Very satisfactory \\
\hline & Adherence to supervision & - & - & 4.50 & Outstanding \\
\hline & Overall mean & - & - & 4.27 & Outstanding \\
\hline \multicolumn{2}{|c|}{ Qualitative description } & - & - & $\mathrm{O}$ & \\
\hline \multirow{5}{*}{$\begin{array}{l}\text { Supervising } \\
\text { instructors }\end{array}$} & Duties and responsibilities & 4.69 & 4.69 & 4.69 & Outstanding \\
\hline & Adherence to policies and standards & 4.20 & 3.91 & 4.06 & Very satisfactory \\
\hline & Adherence to supervision & 4.80 & 4.26 & 4.53 & Outstanding \\
\hline & Adherence to assessment & 4.90 & 4.93 & 4.92 & Outstanding \\
\hline & Overall mean & 4.65 & 4.45 & 4.55 & Outstanding \\
\hline \multicolumn{2}{|c|}{ Qualitative description } & $\mathrm{O}$ & $\mathrm{O}$ & $\mathrm{O}$ & \\
\hline \multirow[t]{4}{*}{ School principals } & Duties and responsibilities & 4.79 & 4.80 & 4.80 & Outstanding \\
\hline & Adherence to supervision & 4.85 & 4.63 & 4.74 & Outstanding \\
\hline & Overall mean & 4.82 & 4.715 & 4.77 & Outstanding \\
\hline & alitative description & $\mathrm{O}$ & $\mathrm{O}$ & $\mathrm{O}$ & \\
\hline \multirow{5}{*}{$\begin{array}{l}\text { Cooperating } \\
\text { teachers }\end{array}$} & Duties and responsibilities & 4.82 & 4.74 & 4.78 & Outstanding \\
\hline & Adherence to supervision & 4.88 & 4.76 & 4.82 & Outstanding \\
\hline & Adherence to assessment & 4.90 & 4.86 & 4.88 & Outstanding \\
\hline & Overall mean & 4.87 & 4.79 & 4.83 & Outstanding \\
\hline & alitative description & $\mathrm{O}$ & $\mathrm{O}$ & $\mathrm{O}$ & \\
\hline
\end{tabular}

\subsubsection{Teacher-trainees}

Table 3 reveals the level of field practices in student teaching of CD, SI, SP, and CT as evaluated by the teacher-trainees. Findings show that teacher-trainees evaluated their CD to be generally outstanding in terms of their duties and responsibilities in student teaching. The teacher-trainees in the BEEd program rated their deans higher than the evaluation made by those from the BSEd program. As regards the CD's adherence to policies and standards, a higher rating was noted on the evaluation made by those from the BEEd program with that of those from the BSEd program notwithstanding the fact that both ratings are categorized as outstanding. In terms of the CD's adherence to supervision, the BEEd teacher-trainees gave them an outstanding rating against the evaluation made by their counterparts which reflects a very satisfactory level of practice. However, the overall result indicates that the deans excellently do their tasks in instructing the supervising instructors to closely monitor the teacher-trainees. In general, the deans were observed to be outstanding in their level of field practices which implies that they exceptionally involved themselves in the student teaching program, a manifestation that the deans are proactive as regards the experiential learning of the student teachers. 
The teacher-trainees of both programs observed their SI to be outstanding in their adherence to assessment, duties, and responsibilities, adherence to supervision, and adherence to policies and standards It could be noted, further, that the teacher-trainees in the BEEd program evaluated their supervising instructors higher than their BSEd counterpart. Results indicate that the teacher-trainees observed their SI to be excellent in the execution of their tasks in student teaching by equipping them with the necessary foundation and processes of Student Teaching Program (STP); evaluating them as regards their academic requirements before their deployment for off-campus teaching; sustaining a purposeful partnership with the Department of Education; and, giving feedbacks, discussing issues, encouraging innovations and diversity, and conducting conferences/colloquium to regularly monitor the progress of teacher-trainees.

The SP were rated by the teacher-trainees of both programs as outstanding in their adherence to supervision, and duties and responsibilities. As usual, it was observed that the teacher-trainees in the BEEd program evaluated their school heads way higher than the BSEd teacher-trainees. Results reveal that the schools remarkably perform their tasks in student teaching by assigning a student teacher to a qualified cooperating teacher; creating a harmonious and functional relationship with their teaching staff and partner agency; packaging and submitting requirements as stipulated in the Memorandum of Agreement (MOA) and conducting pre and post conferences with the $\mathrm{CT}$ and teacher-trainees to regularly thresh out concerns and issues as regards student teaching.

The dimension that got the highest rating was the CT's adherence to assessment followed by their adherence to supervision, and, finally, their duties and responsibilities. A slight difference can be noted between the ratings made by the BEEd teacher-trainees and by the BSEd teacher-trainees. Generally, the teacher-trainees of both programs evaluated their cooperating teachers to be outstanding in their field practices. Results imply that the cooperating teachers were observed by their teacher-trainees to be exceptional in closely checking their lesson plans, how they manage their classroom, and their utilization of instructional materials as well as their personal appearance. Further, the CT were observed to be excellent in requiring the prompt submission of lesson plans and instructional materials and giving feedback to further improve the delivery of the lesson.

Table 3. Level of field practices of mentors in student teaching as observed by the teacher-trainees

\begin{tabular}{|c|c|c|c|c|c|}
\hline \multirow{2}{*}{\multicolumn{2}{|c|}{ Dimensions of field practices }} & \multicolumn{3}{|c|}{ Mean rating } & \multirow{2}{*}{$\begin{array}{l}\text { Qualitative } \\
\text { description }\end{array}$} \\
\hline & & BEEd & BSEd & Overall & \\
\hline \multirow[t]{5}{*}{ College deans } & Duties and responsibilities & 4.93 & 4.80 & 4.87 & Outstanding \\
\hline & Adherence to policies and standards & 4.66 & 4.59 & 4.63 & Outstanding \\
\hline & Adherence to supervision & 4.70 & 4.19 & 4.45 & Outstanding \\
\hline & Overall mean & 4.76 & 4.53 & 4.65 & Outstanding \\
\hline & alitative description & $\mathrm{O}$ & $\mathrm{O}$ & $\mathrm{O}$ & \\
\hline \multirow{5}{*}{$\begin{array}{l}\text { Supervising } \\
\text { instructors }\end{array}$} & Duties and responsibilities & 4.91 & 4.58 & 4.74 & Outstanding \\
\hline & Adherence to policies and standards & 4.70 & 4.65 & 4.67 & Outstanding \\
\hline & Adherence to supervision & 4.89 & 4.48 & 4.69 & Outstanding \\
\hline & Adherence to assessment & 4.91 & 4.60 & 4.75 & Outstanding \\
\hline & Overall mean & 4.85 & 4.58 & 4.71 & Outstanding \\
\hline \multicolumn{2}{|c|}{ Qualitative description } & $\mathrm{O}$ & $\mathrm{O}$ & $\mathrm{O}$ & \\
\hline \multirow[t]{4}{*}{ School principals } & Duties and responsibilities & 4.79 & 4.47 & 4.63 & Outstanding \\
\hline & Adherence to supervision & 4.93 & 4.41 & 4.67 & Outstanding \\
\hline & Overall mean & 4.86 & 4.44 & 4.65 & Outstanding \\
\hline & alitative description & $\mathrm{O}$ & $\mathrm{O}$ & $\mathrm{O}$ & \\
\hline \multirow{5}{*}{$\begin{array}{l}\text { Cooperating } \\
\text { teachers }\end{array}$} & Duties and responsibilities & 4.96 & 4.76 & 4.86 & Outstanding \\
\hline & Adherence to supervision & 4.97 & 4.85 & 4.90 & Outstanding \\
\hline & Adherence to assessment & 4.97 & 4.86 & 4.92 & Outstanding \\
\hline & Overall mean & 4.97 & 4.82 & 4.89 & Outstanding \\
\hline & alitative description & $\mathrm{O}$ & $\mathrm{O}$ & $\mathrm{O}$ & \\
\hline
\end{tabular}

Teacher preparation is indeed part of the issue and part of the solution to the low standard of teaching practices, which suggests that high-quality basic training makes for better quality beginning teachers [28]. Thus, high-quality teacher training is seen to be vital to the form of educational experience obtained by teacher candidates to fulfill the requirements of working in real schools. This scenario could be discerned from the teacher training program's processes and strategies. As a result, the mechanism for a high standard teaching practice of the educational program should concentrate on a systemic and organizational framework that will improve the relevant experience of teacher-trainees [29].

Further, off-campus teaching is an important factor in understanding actual learners, practitioners, and instructional environments and interacts with them. Not only does it make the transition between teaching theory and practice, but it also offers a chance for pre-service teachers to strengthen their specific instructional skills [30]. Also, student teaching is regarded as an integrated element of teacher education 
programs because it offers future teachers the opportunities to pursue the skills and principles they have mastered in instructional situations [31].

\subsection{Relationships between and among the dimensions of field practices of mentors in student teaching and the dimensions of teaching performance of teacher-trainees}

\subsubsection{Dimensions of field practices}

Table 4 presents the association between and among the different dimensions of field practices in student teaching such as duties and responsibilities, adherence to policies, supervision, and assessment. Results reveal that the dimensions of field practices in student internship are significantly interrelated with each other. The field practices in the student teaching program have high significant correlations with duties and responsibilities and with adherence to supervision. However, the adherence to policies and standards and the adherence to assessment have a moderately significant correlation with field practices in the student internship program.

The other dimensions of field practices in the student internship such as duties and responsibilities also showed moderate significant correlations with the adherence to supervision and the adherence to assessment. Conversely, duties, and responsibilities showed a low significant correlation with the adherence to policies and standards.

Although the adherence to policies and standards had a low significant correlation with the adherence to assessment, it showed a moderately significant correlation with the adherence to supervision. Lastly, the adherence to supervision exhibited a moderately significant correlation with the adherence to assessment. Findings imply that when those involved in the student internship program of the study university exhibit outstanding performance in all of the dimensions of field practices, it is tantamount to note that their level of field practices is excellent.

Table 4. Summary for significant relationship between and among the dimensions of field practices of

\begin{tabular}{|c|c|c|c|c|c|}
\hline Variables correlated & Mean & $r_{s}-$ value & $p$-value & Degree of association & Remarks \\
\hline Field practices and & 4.71 & & & & \\
\hline Duties and responsibilities & 4.75 & .717 & $.000 *$ & High correlation & Significant \\
\hline Adherence to policies & 4.65 & .696 & $.000^{*}$ & Moderate correlation & Significant \\
\hline Adherence to supervision & 4.64 & .855 & $.000 *$ & High correlation & Significant \\
\hline Adherence to assessment & 4.82 & .663 & $.000 *$ & Moderate correlation & Significant \\
\hline Duties and responsibilities and & 4.75 & & & & \\
\hline Adherence to policies & 4.65 & .283 & $.000 *$ & Low correlation & Significant \\
\hline Adherence to supervision & 4.64 & .662 & $.000 *$ & Moderate correlation & Significant \\
\hline Adherence to assessment & 4.82 & .504 & $.000 *$ & Moderate correlation & Significant \\
\hline Adherence to policies and & 4.65 & & & & \\
\hline Adherence to supervision & 4.64 & .407 & $.000 *$ & Moderate correlation & Significant \\
\hline Adherence to assessment & 4.82 & .256 & $.000 *$ & Low correlation & Significant \\
\hline Adherence to supervision and & 4.64 & & & & \\
\hline Adherence to assessment & 4.82 & .631 & $.000 *$ & Moderate correlation & Significant \\
\hline
\end{tabular}

Butler's [32] argument that the key issue in learning is being a practitioner, not learning about practice, was reinforced by the findings of this research. Besides, Collins, et al. [33], as quoted by Stoel, van Drie, and Boxtel [34], described four essential features of traditional internship: modeling, scaffolding, fading, and coaching. Modeling, a type of presentation preceded by emulation, is often used as a platform to help learners progress via the Proximal Development Zone [35]. The research of Bandura, as reported by Sanderse [36] has shown that simulation is a more appropriate goal than experimenting. In the simulation, the trainee watches the master explaining how to execute the various parts of the process. The mentor ensures the desired procedures recognizable, often by specifically showing the trainee how to do it. Similarly, for a defined period of time before they begin teaching, the teacher-trainee observes the school supervisor or the cooperating teacher during teaching practice to be able to mimic the supervisor. Scaffolding is the assistance given to interns by the mentor while performing work. This can vary from doing nearly the entire task for them to offering them brief advice about what to do next. Fading is the idea of gradually withdrawing the assistance, offering more and more accountability to the trainee. The teacher-trainee typically works under the mentor's supervision, who will modify their lesson plans and hold pre and post conferences with the trainees to give them pointers and input on their teaching, respectively. Students take increasing responsibility for their teaching over time [33]. 
Also, Marais and Meier [37] emphasized that the student teaching program provides pre-service teachers with a diverse variety of interactions to which they are exposed in classrooms and schools. An integral part of teacher training is student teaching. Student Teaching's ultimate aim is to introduce teachertrainees to the real world of classroom instruction. Teacher-trainees observe teachers at practice during the immersion to learn regarding instructor skills, techniques, and successes in the classroom. It is also the moment where through encounters with teachers and lecturers, they examine their own teaching experiences and through self-reflection, incorporate a range of methods, techniques, and skills to bring about effective learning. It can thus be asserted that student teaching is intended to train preservice teachers for full academic and theoretical proper training by presenting them the foregoing: 1) To supply exposure through involvement and evaluation under the watchful gaze of the universities with which trainees are connected; and 2) To provide skills and experience gained across a plan [38].

\subsubsection{Dimensions of teaching performance}

Table 5 shows the relationship between and among the different dimensions of teaching performance in terms of teacher personality, lesson planning, content, teaching method, classroom management, and questioning skills. Based on the results, teaching performance showed a significant correlation with all its dimensions. That is, teaching performance showed highly significant correlations with the teacher's personality, lesson planning, teaching method, classroom management, and questioning skills. In addition to this, teaching performance exhibited a very high significant correlation with content.

Table 5. Summary for significant relationship between and among the dimensions of teaching performance of

\begin{tabular}{|c|c|c|c|c|c|}
\hline Variables correlated & Mean & $r_{s}-$ value & $p$-value & Degree of association & Remarks \\
\hline Teaching performance and & 1.27 & & & & \\
\hline Teacher's personality & 1.21 & .833 & $.000 *$ & High correlation & Significant \\
\hline Lesson planning & 1.21 & .887 & $.000 *$ & High correlation & Significant \\
\hline Content & 1.31 & .907 & $.000 *$ & Very high correlation & Significant \\
\hline Teaching method & 1.27 & .898 & $.000 *$ & High correlation & Significant \\
\hline Classroom management & 1.23 & .819 & $.000 *$ & High correlation & Significant \\
\hline Questioning skills & 1.39 & .900 & $.000 *$ & High correlation & Significant \\
\hline Teacher's personality and & 1.21 & & & & \\
\hline Lesson planning & 1.21 & .726 & $.000 *$ & High correlation & Significant \\
\hline Content & 1.31 & .693 & $.000 *$ & Moderate correlation & Significant \\
\hline Teaching method & 1.27 & .698 & $.000 *$ & Moderate correlation & Significant \\
\hline Classroom management & 1.23 & .674 & $.000 *$ & Moderate correlation & Significant \\
\hline Questioning skills & 1.39 & 689 & $.000 *$ & Moderate correlation & Significant \\
\hline Lesson planning and & 1.21 & & & & \\
\hline Content & 1.31 & .784 & $.000 *$ & High correlation & Significant \\
\hline Teaching method & 1.27 & .769 & $.000 *$ & High correlation & Significant \\
\hline Classroom management & 1.23 & .686 & $.000 *$ & Moderate correlation & Significant \\
\hline Questioning skills & 1.39 & .726 & $.000 *$ & High correlation & Significant \\
\hline Content and & 1.31 & & & & \\
\hline Teaching method & 1.27 & .815 & $.000 *$ & High correlation & Significant \\
\hline Classroom management & 1.23 & .670 & $.000 *$ & Moderate correlation & Significant \\
\hline Questioning skills & 1.39 & .789 & $.000 *$ & High correlation & Significant \\
\hline Teaching method and & 1.27 & & & & \\
\hline Classroom management & 1.23 & .687 & $.000 *$ & Moderate correlation & Significant \\
\hline Questioning skills & 1.39 & .748 & $.000 *$ & High correlation & Significant \\
\hline Classroom management and & 1.23 & & & & \\
\hline Questioning skills & 1.39 & .722 & $.000 *$ & High correlation & Significant \\
\hline
\end{tabular}

The results further revealed that all of the dimensions of teaching performance are significantly interrelated with each other. A teacher's personality is moderately correlated with content, teaching method, classroom management, and questioning skills. Moreover, the teacher's personality showed high significant correlation with lesson planning. On the other hand, lesson planning is moderately correlated with classroom management but showed high significant correlations with content, teaching method, and questioning skills. Furthermore, content also showed highly significant correlations with teaching method and questioning skills but has a moderate correlation with classroom management. Meanwhile, the teaching method also showed a moderate significant correlation with classroom management but exhibited a high significant correlation with questioning skills. Lastly, classroom management displayed a high significant correlation with questioning skills. Generally, the teacher-trainees of the university manifest a very satisfactory performance in their student teaching and in all of the dimensions of teaching performance. 
In the Philippines, Mahinay [39] stressed that in order to enhance the efficiency of TEIs, teacher training programs should be given great priority. He further articulated that the more doctoral degree holders in the university, the greater the institution of teacher education is since it implies more teaching experience and expertise [16]. Ganal and Andaya [40] pointed out that the challenges and issues faced by teachertrainees were mainly linked to classroom management, communication skills, and instruction skills, among others. It was then proposed that the DepEd should hold a seminar on engagement management.

\subsubsection{Field practices and teaching performance}

Table 6 reflects the relationship between the mentors' field practices and teacher-trainee's teaching performance. The table revealed varied statistical results. When the field practices in student teaching program were correlated with the dimensions of teaching performance, field practices in the student teaching showed no significant relationship with teaching methods and questioning skills. Moreover, although the field practices in student teaching have significant correlations with the other dimensions of teaching performance, field practices in student teaching showed a negative significance but with low correlation with teacher's personality and lesson planning. Since the highest ratings for teaching performance and field practices are 1.00 and 5.0, respectively, the inverse relationship indicates that when the level of field practices of those involved in the STP of the study university is outstanding, the teaching performance of the student teachers in lesson planning and teacher's personality is also excellent. In addition, field practices in student teaching had negligible significant correlation with classroom management.

Table 6. Summary for significant relationship between the dimensions of field practices of mentors in student teaching and the dimensions of teaching performance of teacher-trainees

\begin{tabular}{|c|c|c|c|c|c|}
\hline Variables correlated & Mean & $r_{s}-$ value & $p$-value & Degree of association & Remarks \\
\hline Field practices and & 4.71 & & & & \\
\hline Teacher's personality & 1.21 & -.224 & .001 & Low correlation & Significant \\
\hline Lesson planning & 1.21 & -.235 & $.000^{*}$ & Low correlation & Significant \\
\hline Content & 1.31 & -.186 & .005 & Negligible correlation & Significant \\
\hline Teaching method & 1.27 & -.108 & .106 & Negligible correlation & Not significant \\
\hline Classroom management & 1.23 & -.144 & .031 & Negligible correlation & Significant \\
\hline Questioning skills & 1.39 & -.114 & .088 & Negligible correlation & Not significant \\
\hline Teaching performance and & 1.27 & & & & \\
\hline Duties and responsibilities & 4.75 & -.323 & $.000^{*}$ & Low correlation & Significant \\
\hline Adherence to policies & 4.65 & .066 & .321 & Negligible correlation & Not significant \\
\hline Adherence to supervision & 4.64 & -.240 & $.000 *$ & Low correlation & Significant \\
\hline Adherence to assessment & 4.82 & -.246 & $.000 *$ & Low correlation & Significant \\
\hline Field practices and & 4.71 & & & & \\
\hline Teaching performance & 1.27 & -.184 & .006 & Negligible correlation & Significant \\
\hline
\end{tabular}

Conversely, the findings further indicated that the performance of teacher-trainees showed no substantial association with one of the dimensions of student teaching field practices i.e., adherence to policies and standards. Teaching results, however, showed negative significance but low correlations with responsibilities and duties, supervisory adherence, and appraisal adherence. The opposite relationships indicate that the teacher-trainees showed a very satisfactory teaching performance when the field activities of those participating in STP are especially exemplary in their roles and duties and in their adherence to supervision and evaluation.

Finally, when the field practices in the student teaching program were correlated with the teaching performance of the student teachers, the results showed a negative significance but a negligible correlation between the two variables. However, this significant correlation between the two constructs was determined to be negligible. Thus, the results suggest that the implementation of outstanding field practices in the student teaching program shows minor or slight influence in the outstanding teaching performance of student teachers.

Preservice teacher education is based on the ethical values, experience, and practices of what really means to become a teacher, but it is widely recognized that preservice teacher education does not build or retain an atmosphere that actually adds up to the nature of full-time teaching. It is fair to expect that new teachers will face difficulties in their early years when they join schools that are possibly inexperienced with the specific setting, procedures, learners, and policies that are often in conflict with standards and reality [41]. In addition, as reported by Beltran [42], Gonzalvo, Laksamana, and Sapungan [43], have mentioned that success in student teaching depends largely on the personal and social qualities of teacher-trainees. The milestone also depends upon how teachers trained teacher-trainees to effectively teach, maintain academic 
standards, and other associated components. The teacher-trainee develops a true passion for or an aversion to teaching during the student teaching process. This explains why mentors assigned to assist the teachertrainees must have the skills needed to further improve their teaching skills [44].

\section{CONCLUSION}

The teacher-trainees at the study site constantly demonstrated a very satisfactory teaching efficiency as witnessed by their cooperating teachers and supervisors. Besides, they performed better in the aspects of personality and teaching preparation. This significant performance could be attributed to the quality of education that the University provides to its clientele. Additionally, the College of Teacher Education of the Nueva Vizcaya State University closely adheres to the mandates of the Commission on Higher Education in terms of the policies and standards for teacher education programs. This attribution is made evident through the notable performance of teacher education graduates in the licensure examination.

Those participating in the University's student teaching program consider themselves to have demonstrated remarkable practices in the reflective practice of the teacher-trainees. Teacher-trainees evaluated their mentors to have shown outstanding field practice. In the Philippines, teacher education institutions are expected to continue and provide teacher-trainees with efficiency, reasonable and realistic perspectives, and appropriate experiences. To enhance and deepen their understanding of academic substance and their learning processes, teacher-trainees must be responsive to an optimized and goal-oriented program, so that they can effectively express their thoughts with their learners. This can only be made possible through the impressive supervision provided by their mentors.

When the college deans, supervising instructors, cooperating principals, and cooperating teachers manifested an exceptional level of field practices in student teaching, it follows that all the dimensions of field practices are highly practiced. Further, when the teacher-trainees exhibited an exemplary teaching performance, all other dimensions of student teaching are found to be remarkable. Finally, an outstanding field practice of mentors in student teaching shows minor or slight influence in the outstanding teaching performance of teacher-trainees. The effectiveness of student teaching relies heavily on the individual and interpersonal attributes of teacher-trainees. The breakthrough also varies depending on how educators mold and hone prospective teachers to teach, preserve educational standards, and several other related parts. The teacher-trainee builds up a genuine calling or attachment to teaching during the student teaching process. This illustrates why and how the supervisors delegated to support the teacher-trainees has to have the required skills to even further strengthen their technical skills.

With the foregoing conclusions, the authors forward the following: 1) The administrators of the TEIs and DepEd may see to it that equal opportunity to attend seminars should be given to all supervising instructors and cooperating teachers concerning the student teaching program. It is also recommended that both parties should craft a reasonable flexible incentive system for the benefits of the school principal and cooperating teachers; 2) The supervising instructors of the BSEd program may strongly impose the adherence to policies and standards in student teaching programs; 3) The cooperating teachers may attend more training and seminars on student teaching program to be sponsored by the TEI and DepEd to have more effective teacher-trainees who will be future teachers; 4) Teacher-trainees may be aware of the higher-order thinking skills in the art of questioning during their student teaching program; and 5) Future research is also recommended and encouraged with more characteristics involved in the study.

\section{ACKNOWLEDGEMENTS}

The authors extend their gratitude to the Nueva Vizcaya State University and the Department of Education, Schools Division of Nueva Vizcaya, Philippines for granting the permission to conduct this study.

\section{REFERENCES}

[1] S. Albareda-Tiana, S. Vidal-Raméntol, M. Pujol-Valls and M. Fernández-Morilla "Holistic approaches to develop sustainability and research competencies in pre-service teacher training," Sustainability, vol. 10, no. 10, pp. 1-20, 2018, doi: 10.3390/su10103698.

[2] J. M. Sáez-López, R. Cózar-Gutiérrez, J. A. González-Calero, and C. J. G. Carrasco "Augmented reality in higher education: An evaluation program in initial teacher training," Education Sciences, vol. 10, no. 2, pp. 1-12, 2020.

[3] M. B. Peterson-Ahmad, K. A. Hovey, and P. K. Peak, "Pre-service teacher perceptions and knowledge regarding professional development: implications for teacher preparation programs," Journal of Special Education Apprenticeship, vol. 7, no. 2, pp. 1-16, 2018.

[4] Commission on Higher Education (CMO) 30 series of 2004. Revised Policies and Standards for Undergraduate Teacher Education Curriculum, 2004. [Online]. Available: https://ched.gov.ph/cmo-30-s-2004. 
[5] B. T. Afalla and F. L. Fabelico, "Pre-service teachers' pedagogical competence and teaching efficiency," Journal of Critical Reviews, vol. 7, no. 11, pp. 223-228, 2020.

[6] Department of Education. Guidelines in the Deployment of Pre-service Teachers under Experiential Learning: Field Study and Practice Teaching. Philippines: DepEd, 2007. [Online]. Available: https://deped.gov.ph.

[7] C. T. Biong, "The National Competency-Based Teacher Standards (NCBTS) among the students of the college of education," The Mindanao Forum, vol. 26, no. 1, 2013. [Online]. Available: https://ejournals.ph/article.php?id=7125.

[8] J. MacBeath, Future of teaching profession. Brussels: Education International, 2012.

[9] D. B. Caceres, "Perceived roles of cooperating teachers in student teachers' formation: Input to policy making," Asia Pacific Higher Education Research Journal (APHERJ), vol. 2, no. 1, 2015.

[10] B. Afalla, B. Gabatino, and D. Corpuz, "Experiential Learning Courses: The Outlooks of Pre-Service and InService Teachers," SSRN, 2019, doi: 10.2139/ssrn.3738852.

[11] J. Brandt, M. Barth, E. Merritt, and A. Hale, "A matter of connection: The 4 Cs of learning in pre-service teacher education for sustainability," Journal of Cleaner Production, vol. 279, Jan. 2021, doi: 10.1016/j.jclepro.2020.123749.

[12] P. J. E. Alegado, "The challenges of teacher leadership in the Philippines as experienced and perceived by teachers," International Journal of Education and Research, vol. 6, no. 6, pp. 291-302, 2018.

[13] R. A. B. Calapardo, M. V. Balagtas, and A. G. Dacanay, "Analysis of the student teaching program of selected teacher education institutions and its alignment with the Professional Standards for Teachers," The Normal Lights, vol. 10, no. 1, 2016.

[14] B. O. Ogonor and M. M. Badmus, "Reflective Teaching Practice among Student Teachers: The Case in a Tertiary Institution in Nigeria," Australian Journal of Teacher Education, vol. 31, no. 2, pp. 1-12, 2006.

[15] A. E. Barnes, S. S. Zuilkowskia, D. Mekonnen, and F. Ramos-Mattoussi "Improving teacher training in Ethiopia: Shifting the content and approach of pre-service teacher education," Teaching and Teacher Education, vol. 70, pp. 1-11, Feb. 2018.

[16] M. B. Ulla, "Pre-service teacher training programs in the Philippines: The student-teachers' practicum teaching experience," EFL Journal, vol. 1, no. 3, pp. 235-250, 2016.

[17] R. Salcedo, "Pre-Service Experiences and Performance of Southeast Asian Student Teachers in the SEA Teacher Project," PSU Multidisciplinary Research Journal, vol. 1, no. 1, pp. 1-9, 2018.

[18] M. Syarif Sumantri, A. W. Prayuningtyas, R. Rachmadtullah, I. Magdalena, "The Roles of Teacher-Training Programs and Student Teachers' Self-Regulation in Developing Competence in Teaching Science," Advanced Science Letters, vol. 24, no. 10, pp. 7077-7081, 2018.

[19] Z. Mohamed, M. Valcke, and B. De Wever, "Are they ready to teach? Student teachers' readiness for the job with reference to teacher competence frameworks," Journal of Education for Teaching, vol. 43, no. 2, pp. 151-170, 2017.

[20] M. Haigh, H. Pinder, and L. McDonald, "Practicum's contribution to teacher learning to teach," British Educational Research Association Conference, University of Warwick, England, 2006, pp. 1-17.

[21] J. L. Meneses, et al., "Performances of Pre-Service Teachers in their Practice Teaching and Field Study Courses," Liceo Journal of Higher Education Research, vol. 13, no. 1, pp. 109-124, 2017.

[22] P. Greathouse, B. B. Eisenbach, and J. F. Kaywell, "Preparing Teacher Candidates to be "Effective" in the Classroom: Lessons Learned from National Teachers of the Year," The Clearing House: A Journal of Educational Strategies, Issues and Ideas, vol. 92, no. 1-2, pp. 39-47, 2019.

[23] B. Skinner and L. Abbott, "An exploration of differences in cultural values in teacher education pedagogy: Chinese English language teacher trainees' perceptions of effective teaching practice review," Teacher Development, vol. 17, no. 2, pp. 228-245, 2013.

[24] V. Donche and P. Van Petegem, "Teacher educators' conceptions of learning to teach and related teaching strategies," Research Papers in Education, vol. 26, no. 2, pp. 207-222, 2011.

[25] P. N. Valdez, J. A. Navera, and J. J. Esteron, "What is reflective teaching? Lessons learned from ELT teachers from the Philippines," The Asia-Pacific Education Researcher, vol. 27, no. 2, pp. 91-98, 2018.

[26] R. T. Vecaldo, A. B. Andres, C. G. Carag, and C. B. Caranguian, "Pedagogical competence and academic performance of pre-service elementary teachers in Tuguegarao City, Philippines," Asia Pacific Journal of Multidisciplinary Research, vol. 5, no. 1, pp. 47-54, 2017.

[27] R. A. Somblingo, "Extended practicum in teacher education institutions in Zamboanga City: Status, problems and pre-service teachers' competencies," WMSU Research Journal, vol. 29, no. 2, pp. 1-1, 2010.

[28] S. Cetin, "Development of a scale to measure prospective teachers' self-efficacy beliefs regarding classroom management," Turkish Studies, vol. 8, pp. 299-310, 2013.

[29] C. Adu-Yeboah and C. Yaw Kwaah, "Preparing teacher trainees for field experience: Lessons from the on-campus practical experience in colleges of education in Ghana," Sage Open, vol. 8, no. 4, pp. 1-19, 2018.

[30] N. Brouwer and F. Korthagen, "Can teacher education make a difference?" American Educational Research Journal, vol. 42, no. 1, pp. 153-224, 2005.

[31] K. Akyeampong and K. M. Lewin, "From student teachers to newly qualified teachers in Ghana: insights into becoming a teacher," International Journal of Educational Development, vol. 22, no. 3-4, pp. 339-352, 2002.

[32] R. Butler, "Teachers' achievement goal orientations and associations with teachers' help seeking: Examination of a novel approach to teacher motivation," Journal of Educational Psychology, vol. 99, no. 2, pp. 241-252, 2007. 
[33] A. Collins, J. S. Brown, and A. Holum, "Cognitive apprenticeship: Making thinking visible," American Educator, vol. 15 , no. 3, pp. 6-11, 1991.

[34] G. L. Stoel, J. P. van Drie, and C. AM Van Boxtel, "The effects of explicit teaching of strategies, second-order concepts, and epistemological underpinnings on students' ability to reason causally in history," Journal of Educational Psychology, vol. 109, no. 3, pp. 321-337, 2017.

[35] S. S. Dalton and R. G. Tharp, "Standards for pedagogy: Research, theory and practice," Learning for life in the 21st century: Sociocultural perspectives on the future of education. Blackwell Publishing Ltd, 2002, pp. 181-194, doi: 10.1002/9780470753545.ch14.

[36] W. Sanderse, "The meaning of role modelling in moral and character education," Journal of Moral Education, vol. 42 , no. 1 , pp. $28-42,2013$.

[37] P. Marais and C. Meier, "Hear our voices: Student teachers' experiences during practical teaching," Africa Education Review, vol. 1, no. 2, pp. 220-233, 2004

[38] P. Mtika, "Trainee teachers' experiences of teaching practicum: Issues, challenges, and new possibilities," Africa Education Review, vol. 8, no. 3, pp. 551-567, 2011.

[39] R. B. D. Mahinay, "Contextual performance of teacher education institutions (TEIs) in the Philippines," 2013. [Online]. Available: https://www.researchgate.net/publication/236622259.

[40] N. N. Ganal and O. J. F. Andaya, "Problems of prospective teachers of Philippine Normal University, North Luzon Campus during Practice Teaching," Asia Pacific Journal of Research, vol. 1, no. 28, pp. 59-79, 2015.

[41] R. G. Kane and A. Francis, "Preparing teachers for professional learning: is there a future for teacher education in new teacher induction?" Teacher Development, vol. 17, no. 3, pp. 362-379, 2013.

[42] L. B. Beltran, A Guidebook for the supervision of the student teachers. Rex Book Store. Manila, Philippines, 1992.

[43] B. C. Gonzalvo, G. M. Laksamana, and R. M. Sapungan, "Mentoring practices of English cooperating teachers in public secondary schools," European Journal of Research and Reflection in Educational Sciences, vol. 6, no. 3, pp. 24-33, 2018

[44] C. R. G. Wall, "From student to teacher: Changes in preservice teacher educational beliefs throughout the learningto-teach journey," Teacher Development, vol. 20, no. 3, pp. 364-379, 2016. 